\title{
Comparing Translation Strategies of Two Different Translators of 'Tintin In Tibet'
}

\author{
Theresia Lunetta Thionarto ${ }^{1}$, Julia Eka Rini ${ }^{2}$ \\ English Department, Faculty of Letters, Petra Christian University, Siwalankerto 121-131, Surabaya 60236, \\ INDONESIA \\ e-mails: lunetlunett@gmail.com ${ }^{1}$; jerini@petra.ac.id²
}

\begin{abstract}
This study discusses the differences in Indonesian translations of Tintin in Tibet published by two different publishers. The translation strategies used in these books were qualitatively analyzed using the theory of Mona Baker (2018). The rank of the most dominant strategies, from the most frequent to the less, used by the translators are paraphrase using the unrelated word, paraphrase using the related word, cultural substitution, omission, and less expressive word. The naturalness of the translation is affected by the strategies and by the traits of the character and context. In the translation of swear words, the best strategy used to translate the swear words are cultural substitution. It is better than other strategies because the readers can understand more if familiar swear words are used. In conclusion, both translators have different results of natural translation, but in the translation of swear words, the translator of Indira provides more natural translation.
\end{abstract}

Keywords: Translation, translation strategies, natural, swear words

\section{INTRODUCTION}

The Adventure of Tintin was created by Georges Remi or Hergé on January $10^{\text {th }}, 1929$ and since then, it is known by people of all ages and all around the world until now. The writer chose Tintin in Tibet in this study because there are differences in the translation of Tintin in Tibet into Indonesian from two different publishers, henceforth I and G. It is interesting because both publishers translated the same comic book and also translated it into the same language, Bahasa Indonesia. Due to the number of swear words and casual language used by Captain Haddock, the writer only focused on this character, even though Tintin is the main character. This study aims to know what strategies that the translators used to translate Tintin in Tibet, and which publisher has the most natural translation. The answers to the questions may lead to seeing if there are any differences in the translation strategies that both translators used and how the strategies affect the naturalness of the translation in terms of meaning from certain aspects like idioms, swear words, and other aspects in conversation which is suitable for the situation or the context and more natural to read.

In this study, the writer used the theory of translation strategies from Mona Baker (2018), namely Baker's taxonomy or eight translation strategies. To help the writer analyzing the sentences, the writer made the summary of the characteristics from each strategy: 1) General word in the area of propositional meaning and lack of specificity in the TL; 2) Neutral/Less expressive word when the TL is super-expressive and the SL does not have connotations; 3) Cultural Substitution in order to provide something more familiar for the TL reader; 4) Loan Word and Explanation when dealing with culture-specific items; 5) Paraphrase using the related word when the concept of SL is in the TL, but the form is different; 6) Paraphrase using the unrelated word when the concept of SL is not in the TL and therefore, it is necessary to modify the superordinate to clear the meaning of SL; 7) Omission: Omitting words that are not necessary or when they are used will give a lengthy explanation.; 8) Illustration. To anticipate any non-equivalence above the word level, the writer also used strategies to deal with idioms or fixed expressions. The strategies are: 1) Using an idiom of similar meaning and form; 2) Using an idiom of similar meaning but different form; 3) Borrowing the source language idiom; 4) Translation by paraphrase; 5) 
Thionarto, et al.: Comparing Translation Strategies of Two Different Translators of 'Tintin In Tibet'

Translation by the omission of a play on the idiom; 6) Translation by the omission of the entire idiom. Nevertheless, according to Baker (2018), it is virtually impossible to offer simple guidelines to deal with the various types of non-equivalence which exist among languages. The characteristic of a natural translation based on Mona Baker (2018) is when the translation uses the typical phraseology of the target language, the natural collocation, the own fixed and semi-fixed expression, and the right level of idiomaticity.

\section{METHODOLOGY}

The data contains Captain Haddock's utterances from the beginning of the book until the end. The utterances here means that the writer analyzed the balloon talk of Captain Haddock only. Each utterance was analyzed using Baker's Taxonomy theory and later was classified into each category of the theory. The writer used the following table in analyzing each utterance of Captain Haddock in the comic. TS stands for translation strategies.

Table 1. The table used for analyzing the utterances

\begin{tabular}{|c|c|c|c|c|}
\hline & SL & I & TSI & G T \\
\hline & & & & \\
\hline s Analysi & \multicolumn{3}{|l}{} \\
\hline
\end{tabular}

The whole table for analysis and the discussion part were focusing on contrast and comparison between two publishers. In the result and discussion part, the writer divided the discussion into several parts such as greetings, swear words, and other conversational aspects. This method is used to discuss the differences of the strategies used by the translators from both publishers on how they conveyed the meaning that is most suitable for the situation and context.

\section{FINDINGS AND DISCUSSION}

Both translators used different strategies in dealing with different words in translating the book Tintin in Tibet. From the analysis, the writer found numerous strategies used in translating words in different contexts and situations by both translators and how the strategies affect the naturalness of the translation.

The first strategy is paraphrase using the unrelated word. Both publishers used this strategy often, especially in translating some of the swear words. I used this strategy 137 times while $\mathrm{G}$ used it 96 times. The example below is when both publishers used the same strategy in translating the same utterance.

SL: But this time I shan't give them the pleasure...

I: Tapi kali ini mudah-mudahan tidak... G: Tapi kali ini aku tak sudi...

The first translation is 'mudah-mudahan tidak,' and the other translation is 'aku tak sudi' in translating 'I shan't give them the pleasure.' The first and second translation is faithful with the meaning, but the word choice is different. The context of this utterance is Captain Haddock talking to himself about how usually he is unfortunate when crossing the river, but this time he is not going to give the others the pleasure of watching him fell to the water. The first translation is using 'mudah-mudahan' or 'I hope' which is also has similar meaning with the SL but have different 
vibes compared to the other translation. The vibe of the first translation is softer than the other translation because they used 'aku tak sudi' which is more straightforward. Since the speaker is Captain Haddock and he is talking with himself, the other translation is more natural than the first.

This strategy is also essential because the publishers may be changing the word with something more meaningful or relatable rather than keeping the word and provide a further explanation. Indira used this strategy many times because some words in the SL might not be a perfect fit in Bahasa Indonesia, especially back in the 1970s. It is helping both publishers to be more natural because many words do not fit into Bahasa Indonesia and sound better when they change it.

The second strategy is paraphrase using a related word. Indira used this strategy 97 times while $\mathrm{G}$ used it 98 times. The example below is when both publishers used the same strategy in translating the same utterance.

SL: W-w-what happened? I ate one of those things. It was just like swallowing a volcano in full blast! (p12;c3) berapi.

I: Apa itu tadi? Saya makan buah yang kecil itu satu. Rasanya seperti menelan gunung

ada apa? Kumakan satu, rasanya seperti menelan gunung meletus!

$\mathrm{G}: A-a-$

In the utterance above, the second translation is faithful to the meaning and specific. Those two words, however, have a different meaning in Bahasa Indonesia. In Bahasa Indonesia, 'volcano,' means 'gunung berapi,' and 'gunung berapi' usually refer to a mountain that is still active and can explode anytime. While 'a volcano in a full blast' is specific, so the second translation use 'meletus' instead of 'berapi.' In the context, Captain Haddock is surprised because the thing that he ate is super spicy and burning his mouth. So, he used the term 'volcano in full blast' to describe the spiciness of the fruit. Thus, the second translation is natural because 'meletus' is not only specific but also suitable for the context of the utterance.

The third strategy is omission. Both $G$ and I used this strategy, but $G$ used it more often because $\mathrm{G}$ likes to keep it concise and straight forward. It is proven by the number of times $\mathrm{G}$ used omission in translating some utterances in the book. I used it 16 times while Gramedia used it 63 times. The first example is when both publishers used the same strategy in translating different words.

SL: All right, I'll do it myself... Get my knife... and that's it... Cast off moorings!

I: Baik, baik. Biar saya saja. Mana pisauku?... Sebentar lagi, angkat sauh!

G: Baik, aku saja. Ambil pisau. Angkat sauh!

In the utterance above, both publishers omitted the same word, 'and that's it,' because it is not a significant word. It helps the publishers to be more concise and straightforward. The omission is needed in translation because sometimes, it is not necessary to keep all the words that probably share the same meaning. I used it only a few times, and it makes the translations are mostly as lengthy as the SL while G was trying to keep it concise and straightforward in every translation.

The fourth strategy is cultural substitution. This strategy is used a lot in the translation because since Tintin in Tibet is a different comic, the translator needs to make the reader understand and follow the stories as recognizable as possible. In the translation process, I used this strategy 47 times while $\mathrm{G}$ used it 15 times.

SL: [Singing] Pack up your troubles in your old kitbag and pom pom pom. (p60;c11) I: Buat apa susah. Buat apa susah. Susah itu tak ada gunanya bum bum. 
Thionarto, et al.: Comparing Translation Strategies of Two Different Translators of 'Tintin In Tibet'

\section{G: Naik, naik, ke puncak gunung. Tinggi, tinggi sekali.}

In this context, Captain Haddock is singing because Chang is alive and has been found. The first translation used the song 'Buat Apa Susah' from the band Koes Plus that is released in 1973 to replace the song that the SL use, 'Pack Up Your Troubles In Your Old Kit Bag' by George Henry Powell that was released in 1915. 'Buat Apa Susah' is a viral song, and some people even still know it until now, and it suits the context because it talks about carefree and happiness, the same meaning that the SL song has. On the other hand, the second translation used the famous children song, 'Naik-naik Ke Puncak Gunung,' which talks about the journey of someone climbing a mountain. It suits the situation or the place because Captain Haddock is at the mountain when he sings it, but for the meaning, it is different from the SL song.

The fifth strategy is the general word. I used this strategy seven times while G used it eleven times. The first example is when both publishers used the same strategy in translating different words.

SL: That's lucky: I can just see enough to get up the gangway... (p9;c12)

I: Untung! Pokoknya masih bisa lihat tangga pesawat...

G: Untung aku masih bisa lihat tangganya ...

In this utterance, both translators used general words in translating 'gangway.' However, the first translation used the word 'tangga pesawat' because 'gangway' means a passage for walking primarily on a ship or gangplank. "Tangga pesawat' could be considered as 'gangplank,' so 'tangga pesawat' here is included in 'gangway.' While the other translation chose a similar word but they remove the 'pesawat' or 'plane' and add 'nya' that refers to the plane stairs or 'tangga pesawat.' In this case, the first translation is being faithful to the meaning because 'tangga pesawat' is more specific than 'tangga,' and in real life, people also usually use 'tangga pesawat' to differentiate it from other stairs. While the other translation is used common word by only using 'tangga' but it is understandable because, in the book, the reader can also see the drawing of the plane so they can directly assume that it is a stair to the plane. In terms of naturalness, the second translation is slightly more natural than the first because in real life, when they already in the airport and going up to the plane, it is evident that the stairs are plane stairs, so they probably going to say 'tangganya' instead of 'tangga pesawat.'

The last strategy is neutral/less expressive word. G and I both used this mostly in translating some swear words or insulting words that might sound too rude in Bahasa Indonesia or might giving the wrong connotations. In the process of translation, I used this strategy 11 times while $\mathrm{G}$ used it four times. The first example shown in the table below is when one of the publishers used the strategy in translating the same term. $(\mathrm{p} 4 ; \mathrm{c5})$

SL: Yes, fine... But, I say... this Chang, he's not like that little monster Abdullah, is he?

I: Ya... Tapi ngomong-ngomong, Chang ini tidak seperti Abdullah yang bandel itu, kan?

G: Ya, tapi... Zheng ini, ia tidak seperti Abdallah si monster, kan?

In this utterance, the second translation did not use a less expressive word strategy. While the first translation used it in translating 'little monster' into 'bandel,' which is more neutral or softer than 'little monster' or 'monster kecil.' In this case, if the reader is already familiar with Abdullah or Abdallah, then the use of 'monster' is okay. However, not everyone is familiar with Abdullah, so the word 'bandel' is more suitable because it directly gives the imagery of Abdullah's character to the reader. Therefore, it is way more natural to use 'bandel' rather than 'monster.' 
The next finding is about swear words. Translating swear words could be tricky because it is highly related to culture-specific items or other informal words that are not familiar to people outside the country. Both publishers also have their way of translating the swear words in Tintin in Tibet. Hence, besides the translation strategies used in translating the swear word, the discussion also covered the analysis of swear words used in the book and the differences between the translation result of swear words from both publishers.

The first part of the discussion is about word variation that the publishers used in translating the swear words. It is clear that Indira used various swear words in translating the same swear word, while $G$ remains consistent throughout the book with only using the same word or similar word. In this case, $\mathrm{G}$ is faithful to the meaning and consistent because if they change the words, then they are not faithful anymore. In the other hand, Indira is changing most of the words using different words and not being faithful to the meaning. Indira mostly using the word that is commonly used in Indonesia. Indira chooses words that are familiar for the Indonesian reader, such as 'buset,' 'kampret,' 'brengsek.' However, in G, the word that being translated from the source language is not common in Bahasa Indonesia. No one in Indonesia swears using 'sekarung kepiting kurus' or 'sejuta topan geledek.' Thus, the variation of different swears words that Indira used such as 'sompret,' 'sial,' or 'goblok,' helps the reader to understand that Captain Haddock is swearing at that time and he is either angry or surprised when he said those words.

The second part of the discussion is about the translation strategies that the publishers used in translating the swear words in the book. I used cultural substitution, paraphrase using related word and paraphrase using the unrelated word. In the other hand, $G$ used paraphrase using the related word, paraphrase using unrelated word and less expressive word. I used paraphrase using the related word in translating 'thundering typhoons' into 'topan badai' or 'sejuta topan badai.' However, Indira also used those words in translating other swear words such as 'blistering barnacles.' Paraphrase using unrelated word also used in translating most of the swear words into 'sapi laut,' 'setan laut,' 'kerbau,' or 'monyet,' and many more. Lastly, cultural substitution is the strategy that is used the most in translating the swear words into 'kampret,' 'sompret,' 'goblok,' 'tolol,' and many more. G used less expressive word in translating the swear word 'blistering barnacles,' into 'keterlaluan.' They also used paraphrase using an unrelated word in translating the same swear words as before into 'sekarung kepiting kurus,' or 'sejuta topan geledek.' Finally, they used less expressive word in translating 'blistering barnacles' into 'keterlaluan.'

In terms of naturalness, I tried to pick the most familiar swear words for the Indonesian reader, so even though it sounds rude, the reader can catch the emotion of Captain Haddock and make the stories more alive rather than translating it literally. While $\mathrm{G}$ tried to be balanced because sometimes $\mathrm{G}$ also used certain words that are familiar for the reader, but most of the time, tried to make it as neutral as possible. Overall, I's way of translating swear words in the book was better and more natural because it used Indonesian swear words, and it suits the character of Captain Haddock, so the story is a lot more alive.

Another finding is in the idiom and figurative language part. While the previous two are focusing on the founding of non-equivalence at the word level, the following discussed the nonequivalence that occurred above word level, specifically, idioms. Tintin in Tibet has many idioms, and some of them are interesting to discuss further. The first example is the usage of an idiom that has a similar meaning but in different form and translation by the omission of the entire idiom.

SL: Yes, er... Grand Vizier. And just because he saw Chang alive in a dream, this young whippersnapper got a bee in his bonnet about rescuing him. And because he's as stubborn as a mule, he rushed off to Nepal. And I, like the old fool that I am, came trailing after him. (p49;c6) I: Lya, eh... Wazir Agung. Gara-gara dia mimpi tentang Chang, ia jadi keranjingan ingin menolong kawannya itu. Dan dasar kepala batu, dia langsung berangkat ke Nepal. Entah kenapa saya yang bodoh ini jadi ikut juga... 
Thionarto, et al.: Comparing Translation Strategies of Two Different Translators of 'Tintin In Tibet'

G: Ya, eh, Laksamana Agung. Hanya karena bermimpi Zhang masih hidup, anak muda ini bersemangat sekali menyelamatkannya. Dan saya, dasar bodoh, mengikutinya.

Overall, both publishers used the omission of idiom strategy the most because it is easier to use the literal meaning of the idioms rather than explaining it or using other idioms in Bahasa Indonesia. Thus, both of them could maintain the naturalness of the translation without making the reader confused. However, in some cases, $G$ tends to omit the idiom, which could make the sentence feels incomplete, while Indira still tried to used the meaning of the idiom.

The last discussion is about other things that the writer found when analyzing the utterances, which are different terms of address, particle, and interjections. The first one is the terms of address. Both publishers sometimes used different address terms when they are addressing the same person. The way people addressing someone else also shows the relationship between people, politeness, and also the variety of addresses in a different culture. The first example below is one of the differences.

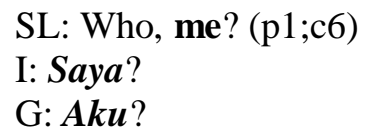

The first translation used 'saya' throughout the book, which is a formal word for 'me' in Bahasa Indonesia. People that close to each other rarely address themselves as 'saya.' Here Captain Haddock is talking with Tintin when they are supposed to have a quite close relationship. Then again, the decision for the second translation to use 'aku' is more natural for Captain Haddock since 'saya' sounds too formal for his character.

Another difference is whether or not using particles.

SL: Hey, Tintin!... What's up with that dog of yours? Look at him. (p25;c8)

I: Hey, Tintin! Kenapa anjingmu itu? Lihat dia.

G: Hei, Tintin, anjingmu kenapa? Lihatlah.

The second translation also used the particle 'lah' at the end of 'lihat' in referring to Tintin's dog. The particle 'lah' was used the most in this book by both publishers. The use of the particle 'lah' here is different from the previous one because it could be because the translator wants to avoid repetition of the subject referred to in the utterance. By using 'lah', it automatically refers to Tintin's dog because they already mention the dog before, so 'lah' here simplify the references.

The last part is interjections which are a word that people use to express their emotions, such as wow, ouch. Both publishers use some interjections in the translation because it helps the sentence to sound more natural. The interjection in Indira is far more well-known for people in Indonesia, such as 'wah,' 'hah,' 'ih.' While G used universal interjection such as 'oh,' 'aw,' and others. The first example of interjections is in the translation below.

SL: Oho! The river... across we go! (p17;c9-c10)

I: Hoho! Sungai. Ayo, nyebrang!

G: Oh! Sungai! Kita seberangi!

Both translations used interjection but with a different word. The first translation used an expression ' $h o h o$ ' to changes 'oho' from the SL because ' $h o h o$ ' is more similar to the voice of laughter but also shows excitement. The second translation used an expression ' $o h$ ' in translating 'oho' because it expresses excitement and surprise at the same time. Overall, interjections are essential to keep the naturalness of the translation and to give the reader better imagery about the emotion of the characters. Since Captain Haddock is a very expressive person, the publisher's 
decision to use interjection is right. Both publishers used the interjections in the right way, so the naturalness is almost the same.

\section{CONCLUSION}

Based on the theory and characteristic of a natural translation, the writer found several noteworthy findings during the analysis. The first one is the rank of each strategy used by both publishers, from the most frequent to the less, which are paraphrase using the unrelated word, paraphrase using the related word, cultural substitution, omission, and less expressive word. Both publishers did not use the loan word and illustration strategy in translating 'Tintin in Tibet.' The writer found that in using the dominant strategies in translating the utterances, the translation results are mostly different. The naturalness is affected not only by the strategies but also by the context of the conversation. Thus, in deciding the best strategy to be used in translating, it is crucial to pay attention to the context and the characters' traits of the characters in order to have a natural translation result.

Following the result of the analysis, the translation of the swear words is also different for each publisher. I uses a different kind of swear words in translating the same swear words. While $\mathrm{G}$ stays consistent with the same translation. This is because the strategies that the publishers used in translating swear words are different. The most used strategy by I is cultural substitution, while $\mathrm{G}$ is paraphrase using an unrelated word. In terms of naturalness, the best strategy for translating swear words is cultural substitution because the readers are familiar with the words or phrases and this can portray Captain Haddock's character entirely.

For idioms and figurative language, both publishers used different strategies in translating the idiom which is using an idiom of similar meaning but a different form, the omission of a play on the idiom, and translation by the omission of the entire idiom. The result of translations from both publishers also considered natural enough because idioms consisted of word-play or unusual terms that can not be translated literally. The writer also found other parts that are also worth to discuss such as: different terms of address, particles and interjections. Those parts are small compared to the other aspects, but they truly helped the publishers to provide natural translation and make the story far more enjoyable.

In conclusion, translators of I and $\mathrm{G}$ do have differences in the translation result in the book 'Tintin in Tibet.' The differences vary from word choices to grammar structure that affect the naturalness of their translation. The translators of Indira tend to be reader-centred because they think about the words that are relatable to the reader, and most of the time, they tried to keep the naturalness of the translation. However, because of that, it is also hard for them to stay faithful with the meaning of the SL since they used words that do not share the same meaning. On the other hand, the translator of $\mathrm{G}$ is more word-centred because they tend to be more consistent with their translation, and most of the time tried to be as neutral as possible. This is also since the translator of $\mathrm{G}$ needs to follow the translation guideline while the translator of I did not have any guide. Moreover, the usage of the right translation strategies such as using cultural substitution in translating swear words can help the publishers to make their translation a lot more natural.

Finally, the writer suggests further research in the future on this particular topic to find out how the reader feels about the translation from both publishers. It will be interesting to see if the reader could spot the differences of translation between two publishers, and how they feel with the translation result. It is also interesting to see further research about the 40 years time-gap between the publishers that was affecting the word choices and variations in the comic. 
Thionarto, et al.: Comparing Translation Strategies of Two Different Translators of 'Tintin In Tibet'

\section{REFERENCES}

Baker, M. (2018). In other words: A coursebook on translation. New York: Routledge.

Cambridge Dictionary. (2020, June 1). Retrieved from Cambridge Dictionary: https://dictionary.cambridge.org/dictionary/english/particle

Hergé / Moulinsart. (2019). Tintin. Retrieved September 9, 2019, from http://en.tintin.com/essentiel

Luebering, J., \& Britannica, T. E. (2017, May 2). Britannica. Retrieved September 9, 2019, from https://www.britannica.com/art/conte-crayon h

Monica, N. S., \& Garnida, S. C. (2014). Translating English noun phrases into Indonesian: Translations strategies for non-equivalence. Parafrase Vol.14 No.02, 25-32.

Nordquist, R. (2020, June 20). ThoughtCo. Retrieved from English Grammar: https://www.thoughtco.com/swear-word-term-1691888

Waskito, A., Nababan, M., \& Santosa, R. (2017). Comparative translation quality of judgement in novel The Adventures Of Tom Sawyer. Lingua Didaktika Volume 11 No 1, 36-52. 